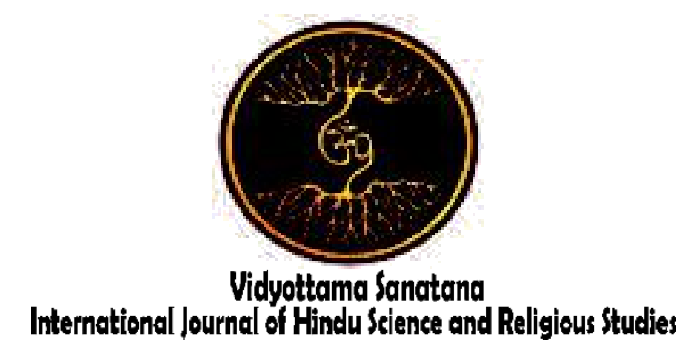

Vol. 2 No. 2 October 2018

\title{
The Implementation Of Karma Yoga Teachings On Religious Life In Denpasar City
}

\author{
By: \\ Ni Made Anggreni \\ Institut Hindu Dharma Negeri Denpasar \\ E-mail : madeanggreni@ihdn.ac.id
}

\begin{abstract}
The development of times and increasingly sophisticated technology, causing human needs to become increasingly complex. In its fulfillment, humans work outside of the teachings of Karma Yoga. There are times when humans work easily but expect maximum results. In the teachings of Karma Yoga, the priority is not the result of the work but the process of that work. The teachings of Karma Yoga are very important to be understood by the community from the essence of work or swadharma that will provide happiness if carried out with responsibility and sincerity. By understanding this teaching, human will achieve happiness both in the world and after die.
\end{abstract}

Keywords: Swadharma, Karma Yoga, Religious Life

\section{Introduction}

Humans basically have two basic needs, namely physical needs and spiritual needs. These needs can only be fulfilled by working. Working very close to human life, because working humans can realize all their dreams. By working humans can explore the whole world. However, humans in work are influenced by their greedy nature. They work minimally but expect maximum results. If the goal in working is not realized, the human will experience stress. Such work methods are not justified in Hinduism. Especially people who live in cities, where the city is the center of economic development. This causes people to work to compete in the economy and fulfill their needs.

Seeing the reality of humans working out of the meaning and nature of real work, this is not in line with working according to the teachings of Karma Yoga contained in the Book of Bhgawadgita. The Book of Bhgawadgita contains the dialogue between 
Krisna and Arjuna amid his doubts in the battlefield because the enemy faced in the war was none other than his own brother, his teacher and Arjuna's own grandfather Bhisma. Arjuna was very guilty when Arjuna fought against his brother and his teacher who educated Arjuna to become a great knight. Arjuna felt there was no point in killing his own innocent brother, instead, Arjuna felt he would be very sinful. In the condition of Arjuna who was shrouded in doubt and haunted by the guilt of the coachman Arjuna, Krishna in Hinduism was believed to be awatara Wisnu gave remarks about Karma Yoga and human swadarma (Bantas and et al. 1994: 27).

The teaching of Karma Yoga does not require high knowledge, but it is enough to be realized by real actions and work. Literally, Karma Yoga means "the way of work or devotion which contains a spirit of high morality to achieve physical and spiritual happiness through work or dedication. The emphasis is on someone's work or work, no matter whether he is an official, farmer, trader and unskilled laborer, even though the most important thing is how they do their best in accordance with their talents and profession.

Everyone has their own swadharmas and fully surrenders the results of their work to Brahman. Thus, people are no longer bound to the results of their work. But people now work far from the teachings of Karma Yoga. The working community which is prioritized is the result of its work which is not the process of that work. People do not understand the teachings of Karma Yoga calmly. Humans who work without being driven by something, not by money, or fame or other motivations are the best workers. From the heart, they will come out an extraordinary workforce, so as to change the antero of human civilization. This kind of humans are the ideals and the highest emissaries of the Karma Yoga journey (Vivekananda, 1991: 122).

The teachings of Karma Yoga are part of Catur Yoga which explains four paths to God. In etymology, Karma Yoga consists of two words, namely "karma" which means the need, work while "Yoga" means connecting with God. So, what is meant by Karma Yoga is how to connect yourself with God through selfless work.

Along with the development of times and increasingly sophisticated technology, human needs are increasingly complex. In its fulfillment, humans work outside of the teachings of Karma Yoga. There are times when humans work easily but expect maximum results. In the teachings of Karma $Y o g a$, the priority is not the result of the work but the process of that work. The teachings of Karma Yoga are very important to be understood by the community so that they can implement this teaching because by understanding it we will achieve happiness both in the world and after die, we can reach the perfection of life.

\section{DISCUSSION}

\subsection{The Implementation of Karma Yoga Teachings}

The implementation according to the meaning of the Indonesian Language Dictionary (Tim Penyusun, 1991: 427) is an absorption element of the English language from the word implementation, in that word is defined as implementation or application. Furthermore, Poerwadarminta (1976: 677) said that the word implementation in the Indonesian dictionary has the same meaning as the application, implementation. So, the word implementation implies the application or implementation of agreed terms, the law that must be obeyed by the person associated with the law.

Implementation, in this case, is a real form carried out by individuals or a group of people in a particular area which is the realization of a consciously determined decision based on a sense of family. In conjunction with this research, the implementation is the implementation of Karma Yoga teachings in the Bhagawadgita book on religious life in Denpasar City.

The Karma Yoga teachings contained in the book Bhagawadgita in the third chapter with the original title Karma Yoga 
with the subject matter of all people in this world must do work activities. Work can bind a person to this world, can also free him from this world bond. People can be freed from the law of karma and achieve unity with the Almighty by acting for the Almighty without selfishness.

Karma Yoga is one of the yoga from Catur Yoga which should be carried out by Hindus. Karma means working and Yoga means connecting with God. So, karma yoga means connecting with God through work. There are also those who say worship through work. In this case, it can be interpreted that working well and correctly is working in Karma Yoga. Understanding Karma Yoga, in general, is working selflessly. Working not while calculating profits and losses. Work diligently and carefully for the success of the job. Work willingly and sincerely for the satisfaction of the client or the person being served. About the benefits or fruits of karma that are picked from the work is handed over to God Almighty (Pidarta, 2005: 40).

Karma Yoga is a part of Catur Marga Yoga which explains the four paths to God. In etymology, Karma Yoga consists of two words, namely "Karma" which means dressing, working while Yoga means connecting with God. So, what is meant by Karma Yoga is how to connect yourself with God through selfless work.

\subsection{The Implementation of Karma Yoga Teachings on Religious Life in Denpasar City}

The concept of the teachings of Karma Yoga in the Bhagawadgita book is very useful if it can be implemented in real life. This concept helps create human happiness both in the world and in the hereafter if it is able to be realized in everyday life. Implementing the teachings of Karma Yoga depends on the level of one's understanding of this teaching.

Gorda (2003: 13) says Hinduism is a living belief based on the sacred teachings revealed by eternal God. These teachings cover all the paths of life to reach happiness, both concerning happiness in the world (jagadhita) and happiness in the afterlife (moksa). The purpose of life according to Hinduism concerns two main aspects to be achieved, namely jadhadhita and moksa. To achieve this goal, humans must work. Work is an active process of thinking (manacika), speaking (wacika), and acting (kayika). A thought process is a form of human work in order to formulate various ideas, ideas, plans, and programs including formulating financing. With the human mind can distinguish good work (subha-karma) and wrong work (asubha-karma) and at the same time, humans gain meaning in their lives and successfully carry out the duties of responsibility.

Speaking or communicating is a form of human work in an effort to socialize the results of the thinking process to form understanding and beliefs which in turn manifest equality of perception to formwork coordination in the diversity of tasks and functions. The role of good communication in one's life, especially in the life of the organization, is basically summarized as follows: (1) words lead to success in life, (2) words will cause failure in life, (3) words cause someone to get something as a source of energy and (4) words cause someone to have a good relationship or friend (Gorda, 2003: 59). Speaking or communicating is a form of human work in developing cooperation, understanding, and encouraging others to work towards achieving the goals they have agreed on.

Doing is a form of human work in an effort to implement various results of the thinking process and the communication process. Doing good is a human potential that is closely related to one's ability to apply their knowledge and skills as an effort to manifest in reality the results of the thinking process (decisions and life policies) and what is said in the lives of both individuals and organizations (Gorda, 2003: 61) These three forms of work in the view of Hinduism are called Tri Kaya Parisudha. The form of human work is to be controlled continuously from the influence of six enemies within us 
(sad ripu). The six enemies in question are working driven by lust (kama), anger (kroddha), greed (lobbha), drunkenness (mada), confusion (maha) and jealousy or malice and not appreciating the achievements of others (matsarya).

What we think shows with good karma, what we say shows with good karma and what we do in accordance with good karmic teachings (Sura, 2008: 23). All forms of thought, words and actions must always be based on good karma. Every form of work, activity (karma) is the cause that will bring consequences, results (phala). The result or outcome is a logical consequence of the work (karma) that we carry out. If we work (in harmony) in a good way or process then the result (phala) is good, we get the opposite if we work in a bad way or process, the results are bad (Astawa, 2008: 12).

In addition to working must control the six enemies that are within us, Work must be in accordance with the teachings of Karma Yoga. As described above each work, action (karma) will bring results (phala). In order for the results of our work to produce a perfect result, it should always be based on the values of the teachings of Hinduism, especially based on the teachings of karma yoga. Thinking, saying, and acting is always based on the values of the teachings of karma yoga so that always what is the essence and purpose of life both concerning worldly happiness (jagadhita) and heavenly happiness (moksa) can be achieved. As described in the Book of Bhagawadgita, III.4 , it is stated:

$\mathrm{Na}$ karman̄ām anārambhān
naishkarmyam purusho ‘’snute
$\mathrm{Na}$ cha samnyasanād eva siddhim
samadhigachchati
Translation:

Without work, people will not achieve freedom, nor perfection because they avoid work activities (Pudja, 2010: 80).

Based on the above sloka, freedom and perfection can be achieved only through work. Work is an obligation, work is Yajna. It needs to be aware that while living in this world, humans cannot be separated from work. Thinking, acting, whatever it is is work. Humans cannot avoid it because it is actually a natural law or prakriti law. Work is a must for everyone. Let us examine together, people who do not work, just lazing their lives to suffer, their lives are miserable from happiness. All that is lacking, is an insult to those around him. Besides working as swadharma, work can also improve human living standards. By working he is respected, by working he is respected, his life is happy away from suffering. This is clarified in the holy book of Bhagawadgita, III-5, as follows:

$\mathrm{Na}$ hi kaschit khsaṇam api jātu tisthaty akarmakrit,

Kāryate hy avasah karma sarvah prakritijair gunaih

Translation:

No one does not work even for a moment because humanity is made helpless by natural law (Darmayasa, 2014: 78).

The teachings of Karma Yoga focus on work actions without being bound by the work itself. We can achieve this by controlling the five senses. People may close their eyes so they don't see the beautiful ones, people may close their mouths so they don't eat well, but if they leave their minds and desires uncontrolled, they fail to apply life discipline. The implementation of the teachings of Karma Yoga in religious life in Denpasar is as follows:

\section{1) Bhakti to Ida Sang Hyang Widhi Wasa}

Hinduism teaches, working is the nature of all humans. Karma yoga provides direction on how to work in this life. Karma Yoga is one way to achieve perfection that focuses on the side of human behavior in everyday life. All actions (Karma) when aimed at the happiness of all beings in the world are a form of Yajna before Ida Sang Hyang Widhi Wasa.

Work has an important role in life. Everyone has been blessed with talent and ability from birth. These talents and abilities will form tasks and obligations in accordance 
with their functions and obligations in the community. By working earnestly and being able to make others happy is a form of devotion to God as explained in the book Bhagawadgita, III-9, as follows:

\section{Yajñärthāt karmaṇo 'nyatra loko' yam karma bandhanah, \\ Tadartham karma kaunteya mukta sanggah samāchara \\ Translation:}

From the purpose of doing yajna, it causes this world to be bound by the law of karma, because it is O Arjuna, working selflessly, without personal interests, O Kunti Putra (Pudja, 2010: 83-84).

All work must be done in a spirit of devotion, devoted to God Almighty. Although this world (including humans) is shackled by the law of work, if the work is carried out without the motive of selfinterest, but for the sake of devotion and service, the fetters no longer have the power to curb.

Next to the Bhagawadgita III-11 Book which reads as follows:

Devān bhāvayatā' nena te devā bhāvayantuyah

Parasparam bhāvayantah śreyah param avāpsyatha

Translation:

With this, praise the gods may the gods bless you with mutual respect as you reach the highest virtue (Pendit, 1996: 89)

The above sloka explained, Krisna taught Arjuna the doctrine which states that humans must worship or respect the Gods as a statement of thanks. Humans who respect these strengths, understand the duty of their lives. For those who understand the highest duty of duty. Worship or respect for the Gods as explained above is not a matter of polytheism or monotheism. For the gods or forces governing the function of the cosmos are no other than Brahman.

Furthermore, in the Book of Bhagawadgita, III-13, explained:

Yajña sishtāsinaḥsanto muchyante sarva kilbishanih,
Bhuñjate te ty aghaim pāpā ye paehanty ātma kāranāt

Translation:

Those who eat well after the devotional ceremony will be released from all sins, but provide delicious food only for themselves. They are actually eating sin (Pendit, 1996: 91)

According to Krisna, good and virtuous people put this service first than their own needs. Sinful people who only provide delicious food for themselves without paying attention to the service that must be done. The form of the above sloka is implemented through Yajna sesa (mesaiban) which is done after cooking in the kitchen. Banten siban as a form of gratitude to Ida Sang Hyang Widhi Wasa along with His manifestations. This Yajna is usually done in the kitchen in a cooking place intended for Lord Brahma, the freshly cooked rice is addressed to Dewi Sri as the fertility goddess, in the place of taking water that is directed to Lord Vishnu, as well as at the place to process or cut ingredients to be cooked like a cutting board. In addition to the kitchen, saiban can also be served in a cake or dish which is directed at the ancestors, and also in the yard, in the tugun reef, and in the river (in front of the house or in front of the entrance).

The Bhakti category can be divided as follows: (1) Devotion to Brahman. Devotion to Ida Sang Hyang Widhi Wasa was realized through the Yajna God Ceremony which is a sacred sacrifice addressed to Ida Sang Hyang Widhi Wasa. The forms of this ceremony are as diverse as Ngodalin, Ngenteg linggih, and others. (2) Being devoted to the forces that govern the cosmos, the devotion to this power is realized through the Bhajna Yajna ceremony. The form of this ceremony is in the form of seguhan and caru. (3) Devotion to ancestors and parents, which is the origin of our birth into the world. Service to ancestors is realized by serving and caring for them as long as they live. Realized through the Pitra Yajna Ceremony. (4) Devote to teachers, the government and to those who are older, who 
deserve to be respected and exemplified. Because the teacher is a teacher and educator. The implementation of this Yajna in everyday life is to practice the teachings of the teacher or the knowledge gained at school. Considering the services of a saint by giving gifts to the Stakeholders and Pandita (5) Devoting to the poor, devoting here is only a term. The real goal is to give alms to the poor, help them alleviate the suffering of life by giving anything according to their abilities. The bhakti is manifested by the manusa Yajna ceremony, which is a ceremony performed on humans from the womb to marriage, (6) Devoting to animals, meaning here giving. Feeding, giving protection, giving love to animals and other living things are included in our dharma as human beings, the most intelligent creatures in the world.

As human beings, we are expected to be human beings who are human, wise and loving to all other beings. Service in Bhagawadgita is clearly described as a life discipline. A disciplined life is nothing but law. The law of life discipline is a cause and effect which is a unity in the relationship of the law of the universe. In other words, the law of cause and effect is the law of life discipline and the law of life discipline is the law of the universe. This must be understood, this must be contemplated and implemented. The implementation is work (Sudharta, 2007: 77).

In addition to work as a form of devotion to Ida Sang Hyang Widhi Wasa, bhakti with the form of work can also be aimed at fellow human beings and the environment. This is in line with the opinion of Wiana (2009: 3) stating achieving a harmonious life by having a harmonious relationship with God with fellow human beings and the environment. Building a harmonious relationship with God with devotion, to fellow human beings with the basis of the world and with the natural environment with compassion.

The purpose of the Hindu community's life which rests on the teachings of Tri Hita Karana, the fact that Hindus are not pursuing their own wealth to become rich without seeing and considering harmony with the society and the surrounding environment. The concept of life and the view of the life of Hindus who prioritize worldly and heavenly balance, material and spiritual harmony that pivot on a good work ethic will underlie socio-cultural phenomena. Thus, the concept of life according to Hinduism is not only to get a decent place in the afterlife if it dies later but also for worldly welfare. This means that people are not justified only to prioritize the afterlife by underestimating the welfare of life on this earth. People mistakenly purify their spirituality by not paying attention to health, nutrition, shelter, income and so on. To fulfill and achieve worldly happiness, humans and Hindus do a job.

By working without being tied to the results of the work, it is a form of maintaining a harmonious relationship with God. By saving a little of our wealth from the results of work is a form of maintaining a harmonious relationship with fellow human beings and by keeping the environment around us is a form of maintaining a harmonious relationship with the environment.

\section{2) As a means of self-control}

The teachings of Karma Yoga as a means of self-control focus on controlling the five senses and controlling lust. The five senses control is mentioned in the book Bhagawadgita III 6-7, as follows:

Karmendriyāni samyamya

Ya āste manasā smaran

Indriyārtān vimūdhātmā

Mithyāchārah sa uchyate

Translation:

He who sits in control of his five faculties but his mind remembers the pleasures that are the object of his senses, in fact he is hypocritical (hypocrites).

Tyas tv indriyāni manasā niyamyā ${ }^{\text {, }}$ rabhate rjuna,

Karmendriyaih karma yogam asktah sa viśishyate 
Translation:

Indeed, the person who can control the five senses with the mind, $\mathrm{O}$ Arjuna, with his senses working without attachment, he is highly respected (Pudja, 2010: 82).

One might close his eyes so as not to see the beautiful, one might close the beginning so as not to eat deliciously, if he left his mind and desire uncontrolled, he failed to absorb the meaning of life discipline. People may be able to withstand their thoughts and desires, if they let their five senses (eyes, mouth, ears, nose and skin) roam, they don't really understand what the meaning of life discipline is. Restraints on the five senses as an introduction to the control of thoughts and desires. In other words, physical control is an introduction to spiritual control.

Control of the five faculties by the mind is very necessary to cleanse the soul of lust and desire. Control of the five senses does not mean stopping activities or work. The control of the five faculties is very important for the concentration of the mind to align all the five senses path activities in the way of good and right actions. Good and right work actions then the mind can be focused on more perfect work and dedication without self-interest. Such action and work can free the soul from the bondage of prakriti and the perfection of life can be achieved.

Lust is the main enemy of humans. If lust has conquered the five faculties, then conquering the heart then conquering the mind is the result of extermination as explained in the Bhagawadgita III 40, as follows:

Indriyāṇi mano buddhir asyā' dhishthānam uchyate,

Ethairvimohayate esha jñānam avvitya dehinam

Translation:

Five senses, mind and intelligence are vehicles for him; the closure of knowledge by him causes confusion in the body (Pudja, 2010: 102).
In accordance with the above explanation, awareness must be grown step by step, which cannot jump at once. First of all, awareness is added from the understanding of the five senses control, then higher to the control of conscience and then to the analysis of the intellect. Ethically, humans must control the five senses first as something very complicated, then control the mind and finally awaken the soul to unite with Atman. With increased awareness. Then the very restless ego in man can be controlled by the light of the eternal soul, with the control of the ego, man achieves the peace of the soul which can easily subdue the passions from within himself.

In religious life in the city of Denpasar, the people do it through daily prayers by doing the Puja Trisandya. And celebrations of religious holy days such as Purnama-Tilem, Saraswati, Siwaratri, Galungan Kuningan and others. Besides, there are also groups (Spiritual Groups) such as Hare Krisna, Brahma Kumaris and others who routinely practice meditation and work as a form of sensory control.

\section{Conclusion}

The implementation of the teachings of Karma Yoga in Bhagawadgita on the lives of religious people in Denpasar City: (1) Bhakti in the presence of Ida Sang Hyang Widhi Wasa. Bhagawadgita explains many ways to worship worship the form of Brahman. In the ordinary way of yoga, by the way of knowledge, by way of meditation, by way of work without expecting profit and by means of peace. Service in Bhagavaddgita is clearly described as a life discipline. Disciplined life is nothing but law. The law of life discipline is a cause and effect which is a unity in the relationship of the law of the universe. In other words, the law of cause and effect is the law of life discipline and the law of life discipline is the law of the universe. This must be understood, this must be contemplated and implemented. The implementation is working according to each task. 


\section{References}

Darmayasa. 2014. Bhagavad Gītà (Nyanyian

Tuhan). Denpasar: Yayasan Dharma Sthapanam.

Pudja, G. 2010. Bhagawad Gītā (Pañcama Veda). Surabaya: Paramita.

Gorda, I Gusti Ngurah. 2003. Membudayakan Kerja Berdasarkan Dharma. Singaraja: Pusat kajian Hindu Budaya dan Prilaku Organisasi STIE Stya Dharma Singaraja.

Vivekananda, Swami. 1991. Karma Marga . Jakarta : Hanuman Sakti.

Pidarta. 2005. Hindu Untuk Masyarakat Umum Pada Jaman Pasca Moderen. Surabaya: Paramita.

Pendit, Nyoman S. 1996. Hindu Dharma Abad XXI. Denpasar: Yayasan Dharma Naradha.
Tim Penyusun, 1996. Pedoman Dosen Agama Hindu.Jakarta : Hanuman Sakti.

Wiana, I ketut,2009. Tri Hita Karana Menurut konsep Hindu.Surabaya : Parami

Poerwadarminta, W.J.S, 1987. Kamus Umum Bahasa Indonesia. Jakarta: Balai Pustaka.

Sudharta, Rai. 2007. Ajaran Moral Dalam Bhagawadgita. Surabaya: Paramita

Astawa, I Nyoman Temon. 2008. Bhakti, Karma, Jnana dan Konsep Taksonomi Serta Kualitas Out Put P.B.M.(Jurnal Sanjiwani, Volume 2, No 1, Halaman 47) 